\title{
Bakthin and the philosophy of the act in research and teaching: An Academic Experience at the Federal University of Pernambuco (Brazil)
}

Maria Cristina Hennes Sampaio ${ }^{1}$

\begin{abstract}
Resumo: O tema deste ensaio foi inspirado na nossa experiência em pesquisa e ensino no Programa de Pós-Graduação em Linguística e Letras, da Universidade Federal de Pernambuco, no Nordeste do Brasil, no período entre 2007-15, a qual resultou na publicação de ensaios, artigos em revistas acadêmicas, capítulos de livros, projetos de pesquisa, dissertações e teses. Neste sentido, pretende-se analisar em que medida o estudo da obra de Bakhtin, Para uma filosofia do ato ético, escrita entre 1920-24, visto sob diversas tradições filosóficas (fenomenologia, ontologia, metafísica e hermenêutica), na disciplina Filosofia da Linguagem, do Programa de Pós-Graduação em Letras, propiciou um profícuo diálogo entre pesquisa e ensino, favorecendo a forma de jovens alunos de iniciação científica, mestrandos e doutorandos abordarem a subjetividade em seus próprios estudos acadêmicos e as consequências de inaugurar um novo lugar de observação ético-filosófica para a pesquisa e o ensino de línguas.
\end{abstract}

Palavras-chave: Bakhtin; filosofia; experiência; pesquisa; ensino.

\begin{abstract}
The subject matter of this paper was inspired in our experience in research and teaching on the Postgraduate Linguistics and Arts Program at the Federal University of Pernambuco, in Brazil's Northeastern region between 2007 and 2015, which led to the publication of papers, academic magazine articles, chapters in books, research projects, dissertations and theses. To that end the intention is to analyze to what extent the study of Bajtin's (1997a) work, Towards a philosophy of the ethical act, written between 1920 and 24, seen from the different philosophical traditions (phenomenology, ontology, metaphysics and hermeneutics) in the Philosophy of Language subject of the Postgraduate Arts Program, offered a fruitful dialog between research and teaching, benefiting the manner in which young people at the research initiation level as well as Masters and Doctorate candidates approach subjectivity in their own academic studies, and the consequences of inaugurating a new place for ethical and philosophical observation for language research and teaching.
\end{abstract}

Keywords: Bakhtin; philosophy; experience; research; teaching.

Introduction

The purpose of this article is to investigate to what extent the study of the work Toward a philosophy of the act by Bajtin (1997a), within the scope of the various philosoph-

1 Assistant Professor at the Department of Letters and Post-Graduate Studies at Federal University of Pernambuco. Post-Doctorate in Studies of Language and Applied Linguistics. Currently engaged in research developed in the field of Philosophy of Language. 


\section{Conexão Letras}

ical traditions, has contributed to redirecting the ways of approaching the subjectivity of our projects and studies and those of our postgraduate students at the Federal University of Pernambuco (UFPE), in the Brazilian Northeast and their consequences for inaugurating another place for ethical and philosophical observation of research into language. We are starting from the assumption that the scientific and philosophical knowledge we have about language is one thing, while the thought experiences we have with it is something else. This presupposes recognizing the existence of fundamental differences between the tasks of reason $(\log o s)$ and of thought. In order to do a thought experiment with language, one cannot rest on a pre-understanding of a world already given, known and explained from a stabilized meaning. Thus, the issues that were prioritized in the studies regarding bakhtinian philosophical ideas seem to indicate that Bajtin's (1997a) philosophy project with regard to experiments with language indicated a different path from that suggested by the sciences, particularly linguistics, metaphysics and psychology, which can only be achieved in lived experience.

\section{The philosophical ethics as a discipline}

Ethics as a philosophical subject presupposes an extensive field of knowledge which, from ancient Greece until nowadays, has raised questions and sought answers regarding mankind's action and morals. In contemporary philosophy the discussion of ethics revisits a basic question of classical metaphysics: what is man? This involves ethics forged in temporariness and by the flow of existence, since being, as was Bajtin's (1997a: 78) intention finds its meaning in temporariness: "only the value of mortal man offers standards for measuring space and time, bearing in mind that space constitutes the possible horizon of this man", while "time atributes to him weight and valuational density". In other words, it is the actual participation of man in his uniqueness that ensures the consolidation of all time and space mathematically possible.

In this sense it is worth pointing out that within the Soviet context of twentieth-century Russian culture, Mikhail Bakhtin, (1895-1975) was one of the few Russian figures to stand out in the field of philosophy and have his ideas recognized and widely disseminated in the West. It is in the work Toward a philosophy of the act. De los borradores e otros escritos, written in his youth, that Bajtin (1997a) defends the ethics of responsibility in the being-event approach, thereby anticipating epistemological and ethical questions concerning the knowledge produced by discursive theoretical thought (natural sciences and philosophy), which from his point of view would be incapable of grasping the beingevent in its uniqueness, arguing that all theoretical reason would only be a moment of practical reason, that is, reason that stems from moral guidance of a subject in the singular experience in being.

Thus, coming back to the concept of the responsible ethical act developed by Bajtin (1997a), we start from the supposition that this ethical knowledge must be sought on a more original horizon than that bequeathed by western tradition, in other words, an ontological and historical point of view.

If the understanding of the responsible act has to be sought in the experience of being in life, one must reflect on the manner in which it appears in existence. To do so, Bajtin (1997a) comes up with the idea of a concrete architectonic of the world of the performed act, guided by value, using it as a counterweight to the analysis of the architectonic of the 
world of the esthetic view with which it shares several characteristics. For him (BAJTIN, 1997a: 60), if the experience of being consists of common constituent moments in their different concrete architectonics, a "moral philosophy should concern itself with describing this architectonic of the real world of the ethical act, not in the form of an abstract scheme, but as a concrete plan of the world of the single and unique act, of the principal moments of how it is structured and of its reciprocal disposition" whose moments are: "the I-for-myself, the other-for-me and I-for the-other". For the philosopher (BAJTIN, 1997a: 61) "all values in real life and culture are set out in spatial-temporal terms around these moments of emotion and volition of the world of the ethical act: scientific, esthetical, political, ethical, social and religious values, etc." For him (BAJTIN, 1997a: 62), "the foundation of the act is found in communion with totality", which is the same as saying that a responsible act does not dissolve in the specialized act, since if it did it would cease to be an ethical act to become a technical action. Thus - he argues - "such an ethical act must not separate theory and thought, but rather include them within itself as necessary and fully responsible moments."

In analyzing the responsible act and the experience of being, Bajtin (1997a) suggests the need to show the manner in which the insertion/appropriation of the act takes place in a singular and unique world experienced in a concrete manner, heard, touched and thought, impregnated with emotional/affective and volitional tonality. In this sense Bajtin, (1997a: 63) insists on the idea that the "uniqueness of the world does not have its origin in any semantic content, since it is of an emotional and volitional order, and what ensures our unique participation in the world is our non-alibi in being". This means that our participation in being is not casual or fortuitous, rather a duty, a commitment, a responsibility to the uniqueness of existence in the experience of being which transforms each of our manifestations into thought, feeling, desire and state of spirit, in an active and responsible act that is exclusively ours. Furthermore, our participation in the experience of being "creates a real gravity of time and a tangible and manifest value of space in the world, converting it to a unique and singular whole, real and experienced in a responsible manner"(BAJTIN,1997a: 64). When this doesn't happen, that is, if we dissociate ourselves "from this center of irradiation" of our "unique participation in being, then this concrete architectonic of a world experienced will be replaced by a systematic unit of abstract and general moments with no temporal-spatial and axiological value" and “its meaning will remain centered on itself”(BAJTIN,1997a: 64-5). On this point, Bajtin (1997a) questions the nature of meaning in its durability, in other words, whether its eternity would be axiologically possible. He argues that if this were possible, that is, if "the eternity of meaning were axiologically valid, then its actual reasoning and achievement through active thought would be unnecessary", insisting that "only in relation to reality, the eternal meaning" - to our mind, that which is already given in reality -, "becomes the driving force of active thought" (BAJTIN, 1997a: 65). In that sense he recognizes the value of eternal meaning, that which is already given, in the totality of the world already given, which is enlightened by the axiological light of a thought actually performed. We can conclude, therefore, that being-in-the-world requires taking into account the relationship of that which is already given and known to be eternal truth, with the single axiological center made possible by the responsibility of the act of thought actually performed. In the next topic we will analyze to what extent thought and language go hand-in-hand. 


\section{A thinking experience with language}

What does it mean to create a thinking experience using language? To answer this question Bakhtin suggests that the living word, the complete word does not merely indicate an object as a one-off entity, rather it expresses our valuational attitude to it, leaving open that which is still to be determined in it. Therefore creating an experience using language would appear to be quite different from acquiring linguistic knowledge of language through linguistic science, philology or psychology, by producing a metalanguage that would be the same as metaphysics in an attempt to apply techniques to languages in order to make them instruments for interplanetary communication.

In post-1920 texts, when discussing the bipolarity of text, Bakhtin (1997b) makes the distinction between two levels of the word: theme and meaning, indicating that the first refers to that unique, non-reiterative element of utterance, its complete sense; the second involves the language level in which the utterance elements are repeatable and identical each time they are repeated, merely constituting a lower level of interpretation. The relationship between "being" and "language", the" worl"" and the "mind", the "given" and the "created" is also a recurrent theme in the philosophical works of Bajtin, as Michael Holquist $^{2}$ points out, clearing the way for the notion of distinctive dialogism which was to be developed in his later works.

Consequently, the idea that the expression of the responsible act demands the plenitude of the word leads the philosopher to question its most original nature in an attempt to extrapolate the thing-word, being-saying relationship. It is language that preserves both the being of things and the manner in which the event happens insofar as it circumscribes the field of our possible experience in the world. Unlike what happens in metaphysics in which language serves to communicate or manipulate the subject, one must recognize that it is language that enables the opening up of the world.

In the next topics we will discuss the outcomes of the contributions of Bakhtin's philosophy of language to our experience in research and teaching on the postgraduate course in Arts of a Brazilian public university.

\section{Research and teaching: experiences on the Graduate Arts Program}

Our experience in research and teaching on the Graduate Arts Program of the Federal University of Pernambuco (UFPE), as leaders of the UFPE-CNPq Language, Society, Health and Work ${ }^{3}$ Research Group and members of the PUC-CNPq Language, Identity and Memory ${ }^{4}$ Research Group, with contributions from the philosophy of language of

2 Preface to the American edition Toward a Philosopy of the Act (Austin: University Press, 1993).

3 The studies and research by this group began in 2002, combining researchers and research initiation students at the UFPE. Research was carried out and resulted in individual and joint publications and in contact and exchanges with other universities: the Language, Identity and Memory Research Group (PU-SP) and the APST - Analyse Pluridisciplinaire des Situations de Travail (Univ.de Provence, France). Nowadays the group is engaged in research and/or is coordinating masters and doctorate theses surrounding the ideas contained in the works of Bakhtin and the Circle and in the dialogic analysis of discourses in different domains: the media, the legal field, literature, art, clinical, educational, health and science in technology in social and occupational relations.

4 The Language, Identity and Memory Research Group created in the year 2000 within the scope of the Postgraduate Studies Program in Applied Linguistics and Language Studies (LAEL - PUC-SP) and certified at the CNPq in 2005, brings together researchers and students from the following universities: the Pontificate 
Bakhtin and other philosophers ${ }^{5}$ with whom he maintained direct or indirect dialog dates from the 2007-10 period with the development of research projects in intervention and social impact, such as Healthy Cities ${ }^{6}$ : a humanist proposal for fostering healthcare for the elderly ${ }^{7}$, in the municipality of Sairé/Pernambuco and Pain and Functional Capacity ${ }^{8}$ : how memory acts during old age $e^{9}$, developed with the participation of students undergoing research initiation, and which resulted in publications of articles and a chapter in the book Concerning the Philosophy of the Act: Bakhtin and scientific research in Human Sciences (2009) $)^{10}$, Life and aging: a philosophical re-reading of Mikhail Bakhtin and Henri Bergson (2010) ${ }^{11}$.

These studies showed it was possible to demonstrate how the responsible act/action mentioned by Bakhtin can be exemplified by the action undertaken by the memory ${ }^{12}$ of the elderly, triggered by the narrative interview and inviting them to act and to create discourse based on closed questions as an act that is both responsible and responsive for constructing and contesting meanings in the uniqueness of the act of being. At no time is the narrative discourse disassociated from the individual's own social condition or indicative of a truth that is given a priori over what is real. On the contrary, from the unique position that an elderly person occupies in the happening of their life's memory, they have a unique an unrepeatable meaning, enunciating from two planes of valuational determination of the world - of an I-for-myself as a human being, occupying a unique place in existence, and an I-for-the-other or others (as an elderly person). When asked by the researcher if anything has changed from when they were young, the elderly person reactivates, from the unique place they occupy in the existence of their life, the memory of the past that extends to the memory of the present:

Catholic University of São Paulo, the University of São Paulo, the Campinas State University, the Federal University of Pernambuco, the Federal University of Uberlândia, the Federal University of Bahia and Paris VIII (France). The group's research revolves around the dialogical analysis of discourse (DAD) of a diverse nature (verbal, verbal and visual, documental and media-based, etc.), the studies of the philosophy of language, education, the history of ideas, studies of Spanish-American anthologies, literacy and teaching, teacher training in the mother tongue and translations of unique texts of Bakhtin and the Circle to Portuguese.

5 As is the case of Frenchman, Henri Bergson, the French-naturalized Lithuanian, Emmanuel Lévinas and the German, Martin Heidegger.

6 Project jointly developed with the UFPE, the State Government of Pernambuco and the Municipal Department of Health of Sairé, Pernambuco State.

7 In Brazil, the projected growth rate of the elderly in the population will remain at around the current $8.6 \%$, rising to $13 \%$ in 2020 , and may reach $20 \%$ of the population in 2050 (IBGE, 1980;1991;2000). The town of Sairé, located in the Agreste region of Pernambuco State, is worthy of note because $10.5 \%$ of the population $(1,857$ people) are over the age of 60 , well above the national average.

8 Project carried out with elderly patients being treated for pain at the Clinics Hospital of the Federal University of Pernambuco.

9 The purpose of the Project was to identify, describe and interpret the meaning of pain, expressed in the appreciative accents found in the discourse of the elderly and its impact on their ability to function.

10 Revista Bakhtiniana, n.1, 2009: pp.42-56. http://www.linguagemememoria.com (last accessed October, 2014).

11 In: Círculo de Bakhtin: diálogos (in)possiveis. Paula, L.de e Stafussa,G. (Orgs.)(Campinas: Mercado de Letras, 2010), pp. 101-22.

12 In Bergson's perception (2005: 18), aging appears to be a vital process in which the inexorable record of time (duration) is written, which implies the existence of an organic memory: 'the strict depth of our conscious existence is memory, in other words, the extension of the past in the present, that is, after all, active and irreversible duration'. 
And how it has changed! It has changed a lot, [...] from water to wine. Because, to begin with, ten or twelve years ago or more, some fifteen or twenty years ago, three o'clock in the morning and I was already starting the day, as they say, getting ready for work, to cut grass, I bred animals... And nowadays I get up at half past five or six, by force, clinging to the wall. As I leave I say to the wife: "I can't even walk these days", but I'm goin' [...] and I come back, I relax, I have a wee one, you know, I take a pill and the struggle goes on... All that's changed is that I want to do things but can't. (AQS, 67 years of age)

As Bajtin (1997a: 48-9) would say, it is the uniqueness of Being that enables the elderly person, from his unique place in being, "to see and get to know someone else" (the young person that inhabits him through memory), that "I don't forget him", that this other person also exists for him. This productive action that only he can produce constitutes the moment of duty in which we assume responsibility for our uniqueness. This doesn't mean that getting old, as a unit of meaning of the world of cognition (science) or culture, does not occupy a moment of being and is valued differently when correlated with the I (the elderly person) and with the other (young person), who are impregnated with totally different volitional emotional tones. "This does not assail the unity of world semantics": on the contrary "it raises it to the very uniqueness level of the event" (BAJTIN, 1997a: 79): "it changed from I want to do" - like the time when I was young, "and cannot do" - nowadays as an elderly person. And what has changed? Scientific literature on the theme describes multiple changes, such as the progressive loss of functional capacity, understood to be the physical and mental skills needed and sufficient for living an independent and autonomous life in order to perform everyday activities (VIEIRA: 1996). The constant change in form is therefore part of every living thing, like a kind of preparation for each phase of growing old.

In 2011 the researcher was awarded a senior post-doctorate scholarship from the National Council of Scientific and Technological Research (CNPq-Brasília) to develop the research project 'Ethics and scientific research in Human Sciences: Philosophical Dialogs with M.Bakhtin' (2011-2012) ${ }^{13}$, under the supervision of Professor Dr. Beth Brait, which led to the publication of Ethics and Human Sciences: philosophical dialogs between M.Bakhtin and E.Lévinas (2012) ${ }^{14}$. Philosophical origins of Ethics in Bakhtin: re-visiting metaphysics and ontological and hermeneutical phenomenology (2012) ${ }^{15}$.

Having concluded her post-doctorate, and on returning to her home university the researcher began a new project: Philosophical origins of Ethics in Bakhtin: re-visiting metaphysics and ontological and hermeneutical phenomenology (2012-2015), which resulted in research initiation sub-projects carried out by supervised teacher training students in Arts: Ethical philosophy of language: understanding Being (2013-2014 - Pedro Henrique de Oliveira Simões); Ethical philosophy of language: ontological coexistentiality of man (2013-2014 - Felipe Diego Batista); Ethical philosophy of language: the return to the authentic/the experience of life and its implications for understanding the event of Being (2014-2015 - Pedro Henrique de Oliveira Simões); Paths of subjective thought to

13 Project developed within the Postgraduate Studies Program in Applied Linguistics and Language Studies at the Pontificate Catholic University of São Paulo, São Paulo-SP.

14 Treatise published in Cadernos de Linguagem e Sociedade, vol. 13 (2), 2012, pp.185-206. http://seer.bee. unb.br/index.php/les (last accessed November, 2014).

15 Paper submitted in 2011, at the $14^{\text {th }}$ International Bakhtin Conference, in Italy, and published in a book organized by Zandwais, A., História das Ideias. Diálogos entre linguagem, cultura e história, by (Passo Fundo: University of Passo Fundo Publishing House, 2012) pp. 192-215. 
become (inter) subjective: implications for understanding the event of being and the responsible and ethical act (2015-2016 - Ricardo Gomes Lima); Ethical Act, the factuality hermeneutics and the event of being: a dialogic-discursive analysis of street demonstrations in Brazil in 2014-2015 (2015-2016 - Ana Elizabeth Oliveira da Silva); dissertations and theses, masters and doctorate projects developed by students on the Postgraduate Arts Program under my guidance: Gender relations: forms of enunciating women's identity in journalism (Dissertation, 2008 - Marcelo Bernardo dos Santos); The discourse of domestic workers in training (Dissertation, 2008 - Joseane Laurentino Brito da Cruz); Software: outline of a study for the Sciences of Language (Dissertation, 2010 - Aguinaldo Gomes de Souza); Discursive dialog analysis of the activity of those caring for the elderly in geriatric institutions in Recife (Dissertation, 2010 - Ludmila Mota de Figueiredo Porto); The activity of distance tutors: a Bakhtinian analysis of what is prescribed and what is experienced in virtual learning environments (Thesis, 2013 - Shirlei Marly Alves); Enunciative discursive analysis of the practical guide for those looking after the elderly (doctorate project, 2014 - Ludmila Mota de Figueiredo Porto); Knowledge building between tutor and undergraduate student in the university: a formative intervention process (2014, Doctorate project - Karla Daniele de Souza Araújo); The value of unpaid domestic work (2015, PhD Project - Joseane Lauretino de Brito); Ethics in Bakhtin as interpretation of the right limit: an analysis of the decision of the Supreme Court in Habeas Corpus 82424 / RS (Master Project - Bruna de Carvalho Chaves Peixoto) as well as the writing of unprecedented studies presented at Brazilian and international congresses, such as $\mathrm{On}$ tological and hermeneutical dimension in the ethical thinking of Bakhtin and Heidegger and the construction of meaning ${ }^{16}$ (2013) and Bakhtin and Heidegger: language as a thinking experience (2014) ${ }^{17}$ and Bakhtin and Heidegger: paths to understanding and interpreting the event of being (2014) ${ }^{18}$; Ways of subjective thought to become (inter) subjective: a philosophical approach to language $(2016)^{19}$.

Below we transcribe the statements by Doctoral candidates about their experiences after reading Toward a Philosophy of the Ethical Act and its impact on the development of their projects:

\section{The discourse of domestic workers in training (Joseane Laurentino Brito da Cruz)}

In her study the researcher analyzed the discourse of domestic workers in the city of Recife who were undergoing a training process organized by one of the most important Brazilian unions - the Central Workers Union (CUT) - whose purpose was to foster educational and vocational training in order to make the category aware of the social value of this activity, encouraging them to fight for more decent working conditions. Below is the researcher's statement:

16 Paper submitted at the VIII GP/CNPq Workshop on Language, Identity and Memory on the ocassion of the $19^{\text {th }}$ National Research Gathering of Applied Linguistics São Paulo, October 2013.

17 Paper submitted in 2014 at the $13^{\text {th }}$ International Conference on the History on the Languages Sciences, at the University of UTAD, Vila Real, Portugal.

18 Paper submitted at the IX GP/CNPq Workshop on Language, Identity and Memory, UFPE, Recife, Pernambuco, in October 2014 and published in the Journal Bakhtinian_vol. 10, n.3, 2015, pp. 186-204; 225-242 http://revistas.pucsp.br.

19 Paper presented at X Journey GP / CNPq Language, Identity and Memory, on the occasion of the 20th National Research Exchange in Applied Linguistics, São Paulo, November 2015 and accepted for publication in the Journal Desenredo, v. 12, No. 1, 2016. 
The aim of our study was to investigate how domestic workers who undertook an educational and vocational training program reacted to the ideas presented by the discourse of training, in other words, how the identity of these workers as a category was constructed in the light of the new concepts introduced by the Citizen's Domestic Labor project. To do so, we resorted to the concepts of 'act' and 'event' in the text Toward a philosophy of the act by Bakhtin, so as to verify how domestic workers understood, added new meaning and reassessed this word during and after the process, since this social and historical 'event' was yet to generate a series of uninterrupted and continuous acts that resulted in a duty, pointing to the transformation of these workers' view through the surplus of vision through which they saw others and, little by little, would adopt his words, sometimes agreeing, sometimes disagreeing with what was said in this inconclusive and uninterrupted dialog between the workers and this entire living universe of words that come together in the discourses that circulate in the social structures in which they found themselves.

\section{The activity of distance tutors: a Bakhtinian analysis of what is prescribed and what is ex- perienced in virtual learning environments (Shirlei Marly Alves)}

In her doctorate thesis, the researcher's objective was to understand the peculiarities of tutoring in distance learning (DL) and its constant redefinitions of the peculiarities in the dynamic of the discursive relations between the tutor and the others (the institution, professors and students). For Alves,

(...) the conception of language to carryout out (sic) the work of the analyst of the study can only be that whose primacy is to be found in the relation between subjects, whose construction takes place within the uninterrupted dynamic of situated discourses that engender forms of life within the dialogical arena in which human beings are to be found.[...] One can see the convergence between this conception of the act in Bakhtin and that of activity, in line with the ergological episteme, since in both cases human action takes place in unique events with their inherent peculiarities. Therefore they can only be grasped within the contact between the researcher and the subjects in their exist-event, just like workers considered not as objects to be observed, but primarily as unique beings who in their day-to-day working lives exercise competences constructed and reconstructed based on their history, emotions, memories and other elements of a subjective nature.

\section{Enunciative discoursive analysis of the practical guide for those looking after the elderly (Ludmila Mota de Figueiredo Porto)}

In her doctorate thesis Project Porto continued her studies into the activities of those caring for the elderly in geriatric institutions in the city of Recife ${ }^{20}$, thereby returning to the dialogical analysis of the discourses to be found in three technical manuals for minders recognized by the Brazilian Ministry of Health. In her study she argues in favor of applying the "ethical act of caring for elderly human beings", asserting "that ethical caring" must always underlie "all other models of caring", since the "caring being" is, above all else, an ethical duty that serves as a "guide for the relationships of caring among human beings themselves". Below is the researcher's statement:

20 Three long-stay institutions in the city of Recife that are home to around 30 elderly people, who receive daily care from nurses and minders, took part. 
During my doctorate I took the subject of the Philosophy of Language with Professor Maria Cristina Hennes Sampaio, who guided me on my thesis, which amplified the discussion surrounding the works of Bakhtin, based on Toward a philosophy of the act, a work I consider essential for understanding what Bakhtin refers to as the First Philosophy and whose study subject is the ethical act in its eventicity, which is dealt with at the confluence of content-meaning and the historical reality of its happening in which it acquires an axiological hue. Reading the work is essential for understanding the Bakhtinian vision of language, the concrete act also being an act of language, a responsive act in a responsible manner with the other. The dialogical relationships established with other texts of Bakhtin and other philosophers, for example Heidegger and Kant, were extremely important for my education in Bakhtinian studies, as well as for producing my thesis which discusses the 'concrete act' and the 'event of being' as key elements for understanding the caring being. In my view, Towards a Philosophy of the Act is the work that at the same time initiates and enables the finalization, albeit temporary, of the meaning in Bakhtin. In my view, Towards a Philosophy of the Act is the work that at the same time initiates and enables the finalization albeit temporary, of the meaning, in Bakhtin.

\section{Knowledge building between instructor and undergraduate student in the university: a formative intervention process (Karla Daniele de Souza Araújo)}

In her doctorate Project Araújo analyses how knowledge is built between an undergraduate student and tutor in a Postgraduate Arts Program at a Brazilian public university. The researcher sees academic guidance as a formative space in which socially and historically situated subjects present their requirements and, in the search for solutions, establish a dialogical discursive relationship, challenging and evaluating point of view, reconstructing sense and sharing meanings. In this respect the historical subject would be the one who experiences the world from his unique and singular place, assuming his thoughts and actions as responsible ethical acts from which he cannot escape. This is what he had to say:

(...) man does not come into the world to investigate objects, he is in the world, and from within this overture he is launched along with things, whence he can get to know them, experiencing them. The truth, like an overture, thus responds to the truth of being as an event which becomes the ontological truth (when compared with the ontic truth of being). The overture idea destabilizes scientific doing by checkmating its methods and objectives. In other words, if we can no longer rely on meeting the truth as the culminating moment of the research, where will this point to? (...) As it is impossible to deny the multiplicity of looks, and by understanding that there no such thing, a priori, as an absolute truth, one has to recognize doubt as a value that is the basis of our lives for as long as we are alive, and this in no way conflicts with theoretical cognition, rather it only assumes the mankind's way of being as a project, possibility and power.

\section{Teaching experience: introduction of the Philosophy of Language course}

The experience with the introduction of the subject of Philosophy of Language, introducing the philosophical ideas of Bakhtin, took place in a somewhat experimental manner back between 2007 and 2010 following the enrollment of a small but interested group of students, and our object was to offer an extensive overview of the philosophical fundamentals of the principal theses of Bakhtin and the Circle, taking into account their epistemological and methodological principles, as well as their implication and applications for research in Human Sciences. The outcome of this work is described below: 
Chart1 ${ }^{21}$

\begin{tabular}{|c|c|c|}
\hline Author and Year & Title of the study & Purpose \\
\hline $\begin{array}{l}\text { Adelmo Galindo } \\
\text { (Masters candidate - } \\
2007)\end{array}$ & $\begin{array}{l}\text { Reflections anchored in } \\
\text { Bakhtin: the subject and } \\
\text { language }\end{array}$ & $\begin{array}{l}\text { To deal with - based on two Bakhtinian works (Towards } \\
\text { a philosophy of the ethical act and Marxism and the } \\
\text { Philosophy of language) -, the ideas of subject and } \\
\text { language, particularly emphasizing human interaction } \\
\text { through the language in use (whether spoken or written). }\end{array}$ \\
\hline $\begin{array}{l}\text { André Alexandre } \\
\text { Padilha Leitão } \\
\text { (Doctoral candidate - } \\
\text { 2007) }\end{array}$ & $\begin{array}{l}\text { The architectonic of the } \\
\text { responsibility of Web } \\
2.0 \text { and the question of } \\
\text { authorship. }\end{array}$ & $\begin{array}{l}\text { To investigate the construction of the responsive subject } \\
\text { in the web } 2.0 \text { as the author of content produced on open } \\
\text { collaborative sites, primarily on Wiki sites, based on the } \\
\text { categories of act/activity, event, ethics and responsibility } \\
\text { of Mikhail M. Bakhtin. }\end{array}$ \\
\hline $\begin{array}{l}\text { Carolina Leal Pires } \\
\text { (Masters candidate - } \\
\text { 2007) }\end{array}$ & $\begin{array}{l}\text { Where is Bakhtin? } \\
\text { Seeking to identify } \\
\text { contribution of } \\
\text { Bakhtinian thought to the } \\
\text { Semiolinguistic Analysis } \\
\text { of Discourse. }\end{array}$ & $\begin{array}{l}\text { To identify the contributions of Bakhtinian thought to the } \\
\text { Semiolinguistic Analysis of Discourse. }\end{array}$ \\
\hline $\begin{array}{l}\text { Gerenice Ribeiro } \\
\text { de Oliveira Cortes } \\
\text { (Masters candidate - } \\
\text { 2007) }\end{array}$ & $\begin{array}{l}\text { Dialogism and Alterity in } \\
\text { Scientific Discourse. }\end{array}$ & $\begin{array}{l}\text { To analyze to what extent dialogism and Alterity appear } \\
\text { and constitute scientific discourse, as the latter, in the } \\
\text { rationalist tradition, is conceived as neutral and objective. }\end{array}$ \\
\hline $\begin{array}{l}\text { Josemar José Barbosa } \\
\text { (Doctoral candidate - } \\
\text { 2007) }\end{array}$ & $\begin{array}{l}\text { Alterity and Dialogism: } \\
\text { the eternal search for the } \\
\text { Other. }\end{array}$ & $\begin{array}{l}\text { The study intends to discuss the following issues: what to } \\
\text { do when the desire to communicate is superimposed by the } \\
\text { frustrating inability to reveal oneself to the other? What } \\
\text { mechanisms do subjects use in their constant search to } \\
\text { discover themselves? Can one build oneself without firstly } \\
\text { implying the construction of the other? }\end{array}$ \\
\hline $\begin{array}{l}\text { Maria Aldenora Cabral } \\
\text { de Araújo (Masters } \\
\text { Candidate - 2007) }\end{array}$ & $\begin{array}{l}\text { The dialogical role of } \\
\text { discursive memory in } \\
\text { written productions in } \\
\text { the English Language as } \\
\text { a foreign language. }\end{array}$ & $\begin{array}{l}\text { To understand the role of discursive memory in a } \\
\text { speech project between Mother Tongues and the English } \\
\text { Language. }\end{array}$ \\
\hline $\begin{array}{l}\text { Ludmila Mota de } \\
\text { Figueiredo Porto } \\
\text { (Doctoral candidate - } \\
\text { 2010) }\end{array}$ & $\begin{array}{l}\text { Pêcheux and Bakhtin } \\
\text { at their roots: } \\
\text { approximations. }\end{array}$ & $\begin{array}{l}\text { Redeeming some of the concepts in the works of Pêcheux } \\
\text { and Bakhtin, establishing approximations between the } \\
\text { theoretical identities of their proposals. }\end{array}$ \\
\hline $\begin{array}{l}\text { Rita de Kássia Kramer } \\
\text { Wanderley (Masters } \\
\text { candidate - 2010). }\end{array}$ & $\begin{array}{l}\text { Act and responsibility in } \\
\text { the moral philosophy of } \\
\text { Towards a philosophy of } \\
\text { the responsible act. }\end{array}$ & $\begin{array}{l}\text { To reflect on certain concepts put forward by the author } \\
\text { and debated during our studies in the subject. }\end{array}$ \\
\hline $\begin{array}{l}\text { Shirlei Marly Alves } \\
\text { (Doctoral candidate - } \\
2010 \text { ) }\end{array}$ & $\begin{array}{l}\text { Instinct: antipodes of } \\
\text { investigation in Human } \\
\text { Sciences. }\end{array}$ & $\begin{array}{l}\text { To verify how the Bakhtin's concept of the responsible } \\
\text { ethical act is associated with the action of two figures } \\
\text { (the anthropologist Ethan Powel and the psychiatrist } \\
\text { Theo Caulder), in the cinematographic work Instinct } \\
\text { (directed by Jon Turteltaub, 1999), so as to contribute to } \\
\text { a discussion on the researcher's attitude to the other party } \\
\text { - the one being researched -, within the scope of Human } \\
\text { Sciences. }\end{array}$ \\
\hline
\end{tabular}

During the first semester of 2011 I took leave of absence from the UFPE to do a post-doctorate at the Pontificate Catholic University of São Paulo, on the Postgraduate Studies Program in Applied Linguistics and Language Studies under the supervision of

21 End-of-course papers submitted between 2007 and 2010 by the students reading Philosophy of Language. 
professor Beth Brait, with the project 'Ethics and scientific research in Human Sciences: Philosophical Dialogs with M. Bakhtin'22. In the second semester of 2012 I returned to my academic activities at the UFPE and in 2013 I went back to offer the subject Philosophy of Language, now with the purpose and the program reformulated to take into account, within the ethical and philosophical fundamentals of the principal theses of Bakhtin and the Circle regarding the Philosophy of Language, the contributions of Phenomenology, Metaphysics, Ontology and Hermeneutics ${ }^{23}$ that guide them, and their implications and applications in research in Human Sciences. The following chart illustrates the papers submitted by the students at the end of the semester:

\section{Chart $2^{24}$}

\begin{tabular}{|l|l|l|}
\hline Author and Year & Title of the study & \multicolumn{1}{|c|}{ Purpose } \\
\hline $\begin{array}{l}\text { Adiniz Mendes } \\
\text { (Doctoral candidate }-\end{array}$ & $\begin{array}{l}\text { Several Bakhtinian } \\
\text { concepts on Human } \\
\text { Sciences }\end{array}$ & $\begin{array}{l}\text { To reflect and synthesize Bakhtin's view of Human Sciences } \\
\text { based on the text The problem of text in Linguistics, Philology } \\
\text { and other human sciences: an experiment in Philosophical } \\
\text { Analysis; Methodology of Human Sciences and From Notes } \\
\text { made in 1970-71. }\end{array}$ \\
\hline $\begin{array}{l}\text { Carla Richter (Masters } \\
\text { candidate - 2013) }\end{array}$ & $\begin{array}{l}\text { In the spider webs of } \\
\text { singularity: dialogs } \\
\text { between Bakhtin, } \\
\text { Applied Linguistics } \\
\text { and the Theory of } \\
\text { Social, Historical and } \\
\text { Cultural Activity }\end{array}$ & $\begin{array}{l}\text { To put into dialogue the philosophical thinking of Bakhtin, } \\
\text { Applied Linguistics and the Theory of Social, Historical and } \\
\text { Cultural Activity. }\end{array}$ \\
\hline $\begin{array}{l}\text { Erasmo da Silva } \\
\text { Ferreira (Masters } \\
\text { candidate - 2013) }\end{array}$ & $\begin{array}{l}\text { Bakhtin and } \\
\text { Heidegger: a } \\
\text { contribution to } \\
\text { the Philosophy of } \\
\text { Language }\end{array}$ & $\begin{array}{l}\text { To reflect on the philosophical nature of language in the views } \\
\text { of Bakhtin (Towards a philosophy of the act) and Heidegger } \\
\text { (Being and Time). }\end{array}$ \\
\hline
\end{tabular}

22 This study opted to revisit issues that are very much to the fore in Bakhtin's work Hacia una Filosofia del Acto Ético. De los borradores e otros escritos (Barcelona: Anthropos, 1977) - such as being-person, manexistence and being-alterity-responsibility relations and which were revisited in the dialogic confrontation of the works: El ser y el tempo, by German philosopher Martin Heidegger (El Salvador/Buenos Aires: Fondo de Cultura Económica, 2010), and Entre nós: ensaios sobre a alteridade, by the Lithuanian naturalized Frenchman, Emmanuel Lévinas (Stefano Pivatto Petrópolis: Editora Vozes, 2009).

23 As Caryl Emerson has already pointed out in the work Os 100 primeiros anos de Mikhail Bakhtin (Trans. Pedro Jorgensen Jr., Rio de Janeiro: Difel, 2003, 19), 'there is no clear indication where the philosophical tradition came from that nurtured him and is still to be clarified', since in the body of the work itself there are scant references by Bakhtin to other philosophers, as is the case of Germany's Immanuel Kant, Heinrich Rickert (neo-Kantian), Hermann Cohen, Friedrich Nietzsche, Arthur Schopenhauer or Frenchman Henri Bergson and England's Thomas Hobbes. The others are the responsibility of the translators and appear in footnotes, or are allusions in the prefaces and postscripts of the editions translated in Europe, the United States and South America. As Faracco states in the postscript to the Brazilian edition of the work "Para uma filosofia do ato responsável" (Translation by Valdemir Miotello and Carlos Alberto Faracco, São Carlos: Pedroejoaoeditores, 2010, p. 149), the minor importance attributed by Bakhtin to quotations and references is well-known, and he is credited with having said that 'they were unnecessary for competent readers and useless to those not qualified'. Whether we agree, or not, with Bakhtin, the fact is that the young philosopher with a solid education in classical studies and who read in fluent German had encounters with several traditions such as Greek philosophy, phenomenology, hermeneutics, ontology and metaphysic - as witnessed by his writings dating from 1920 .

24 End-of-course paper in 2013 in the subject Philosophy of Language. 


\begin{tabular}{|c|c|c|}
\hline $\begin{array}{l}\text { Felipe Augusto } \\
\text { Santana do } \\
\text { Nascimento (Masters } \\
\text { candidate - 2013) }\end{array}$ & $\begin{array}{l}\text { Two or three points } \\
\text { on singularity and } \\
\text { responsibility in } \\
\text { scientific research } \\
\text { in human sciences: } \\
\text { considerations } \\
\text { based on Towards a } \\
\text { philosophy of the act } \\
\text { by M. Bakhtin. }\end{array}$ & $\begin{array}{l}\text { To discuss, based on the work Towards a philosophy of the act } \\
\text { by M.Bakhtin, the implications of the concepts of singularity } \\
\text { and responsibility for scientific research in Human Sciences - } \\
\text { more specifically in language studies. }\end{array}$ \\
\hline $\begin{array}{l}\text { Karla Daniele } \\
\text { De Souza Araújo } \\
\text { (Doctoral candidate - } \\
\text { 2013) }\end{array}$ & $\begin{array}{l}\text { On Science and Man: } \\
\text { a treatise on ethical } \\
\text { knowledge. }\end{array}$ & $\begin{array}{l}\text { To reflect on the building of knowledge between masters } \\
\text { candidates and their tutors in the social activity of academic } \\
\text { guidance, with the focus on the dynamic of (re)producing } \\
\text { knowledge. }\end{array}$ \\
\hline $\begin{array}{l}\text { Romana Maria } \\
\text { Moreira (Master of } \\
\text { Philosophy - 2013) }\end{array}$ & $\begin{array}{l}\text { Hermeneutic } \\
\text { contributions in the } \\
\text { discourse of Bakhtin's } \\
\text { philosophy of the } \\
\text { ethical act. }\end{array}$ & $\begin{array}{l}\text { To identify and apply hermeneutic fundamentals to the } \\
\text { discourse of the work Towards a Philosophy of the Act, by } \\
\text { Bakhtin, using a methodology centered on applying the } \\
\text { fundamentals of hermeneutic philosophy. }\end{array}$ \\
\hline $\begin{array}{l}\text { Thais de Andrade } \\
\text { Lima (Masters - 2013) }\end{array}$ & $\begin{array}{l}\text { Participative thinking } \\
\text { in Bakhtin: steps } \\
\text { taken in Towards a } \\
\text { philosophy of the act. }\end{array}$ & $\begin{array}{l}\text { To consider, in a participative manner, the theoretical } \\
\text { constructs developed in an interconnected manner, such as } \\
\text { the ethical act and the architectonic of being, and to reflect } \\
\text { on the methodological results of a thought arising from the } \\
\text { singularity of the ethical act for the studies of language. }\end{array}$ \\
\hline $\begin{array}{l}\text { Rita de Kássia Kramer } \\
\text { Wanderley (Masters } \\
\text { candidate - 2010). }\end{array}$ & $\begin{array}{l}\text { Act and responsibility } \\
\text { in the moral } \\
\text { philosophy of } \\
\text { Towards a philosophy } \\
\text { of the responsible act. }\end{array}$ & $\begin{array}{l}\text { To reflect on certain concepts put forward by the author and } \\
\text { debated during our studies in the subject. }\end{array}$ \\
\hline $\begin{array}{l}\text { Shirlei Marly Alves } \\
\text { (Doctoral candidate - } \\
2010 \text { ) }\end{array}$ & $\begin{array}{l}\text { Instinct: antipodes } \\
\text { of investigation in } \\
\text { Human Sciences. }\end{array}$ & $\begin{array}{l}\text { To verify how the Bakhtin's concept of the responsible } \\
\text { ethical act is associated with the action of two figures (the } \\
\text { anthropologist Ethan Powel and the psychiatrist Theo } \\
\text { Caulder), in the cinematographic work Instinct (directed by } \\
\text { Jon Turteltaub, 1999), so as to contribute to a discussion on } \\
\text { the researcher's attitude to the other party - the one being } \\
\text { researched -, within the scope of Human Sciences. }\end{array}$ \\
\hline
\end{tabular}

\section{Chart $3^{25}$}

\begin{tabular}{|l|l|l|}
\hline Author and Year & Title of the study & Purpose \\
\hline $\begin{array}{l}\text { Arcélio Alves Fortes } \\
\text { (Masters - 2015) }\end{array}$ & $\begin{array}{l}\text { Being and Age: } \\
\text { introductory analysis } \\
\text { of the age limit } \\
\text { change for adolescents } \\
\text { and elderly from } \\
\text { the perspective } \\
\text { of Bakhtin's } \\
\text { architetonics. }\end{array}$ & $\begin{array}{l}\text { Contribute, through the analysis of individual perceptions in } \\
\text { the context of the diversity of Brazilian regions and offered } \\
\text { life's quality for the population, with current discussions } \\
\text { regarding the age limit modification to legal age and } \\
\text { retirement, under the approach of being, exposed by Bakhtin } \\
\text { in Towards a Philosophy of the Ethic Act. }\end{array}$ \\
\hline $\begin{array}{l}\text { Bruna de Carvalho } \\
\text { Chaves Peixoto } \\
\text { (Masters 2015) }\end{array}$ & $\begin{array}{l}\text { The interpretative } \\
\text { dynamism of the } \\
\text { legal discourse of the } \\
\text { Supreme Court in the } \\
\text { decision on racism: a } \\
\text { dialogical analysis of } \\
\text { the responsible act. }\end{array}$ & $\begin{array}{l}\text { Analyze, taking as theoretical basis bakhtinian dialogism, } \\
\text { the concept of responsiveness and ethics, the role of the } \\
\text { ideological historical social context in STF decisions about } \\
\text { controversial issues_specifically the judgment by which it } \\
\text { was decided that the Jews against hate speech was considered } \\
\text { racist crime and would be imprescriptible, as provided in the } \\
\text { Constitution. }\end{array}$ \\
\hline
\end{tabular}




\begin{tabular}{|c|c|c|}
\hline $\begin{array}{l}\text { Ceuline Maria } \\
\text { Medeiros Santiago } \\
\text { (Graduate student - } \\
\text { 2015) }\end{array}$ & $\begin{array}{l}\text { Ethics and Social } \\
\text { Gender: a reading of } \\
\text { Hacia una Filosofia } \\
\text { del Acto Ético. }\end{array}$ & $\begin{array}{l}\text { This study aims to reflect on being in the real and concrete } \\
\text { context experienced at real life, considering the theoretical } \\
\text { determinations that intend to concieve a single way of } \\
\text { being a woman and a man. In which place, under these } \\
\text { determinations, would be the irrefutable singularity of } \\
\text { being? How to conceive such a singularity at the heart of } \\
\text { stuck relations between beings in the world? There would be } \\
\text { an ethical sense in being a woman and being a man? }\end{array}$ \\
\hline $\begin{array}{l}\text { Iago de Araújo Pereira } \\
\text { Broxado (Masters - } \\
\text { 2015) }\end{array}$ & $\begin{array}{l}\text { The role of the } \\
\text { educational } \\
\text { coordinator in a } \\
\text { language course for } \\
\text { student mobility - a } \\
\text { reflection. }\end{array}$ & $\begin{array}{l}\text { This study aims to understand how the pedagogical } \\
\text { coordinator (CP) contributes to the occurrence of the } \\
\text { production of knowledge shared during interactions with } \\
\text { teachers that compose the teaching course staff. }\end{array}$ \\
\hline $\begin{array}{l}\text { Joseane Laurentino } \\
\text { Brito (Doctoral } \\
\text { candidate - 2015) }\end{array}$ & $\begin{array}{l}\text { The ethical act and } \\
\text { the event of being in } \\
\text { Bakhtin. }\end{array}$ & $\begin{array}{l}\text { The study aims to discuss the concepts of "act" and "being- } \\
\text { event" present in Bakhtin's work (1997), For a philosophy of } \\
\text { the act, relating them to the speech of women who carry out } \\
\text { unpaid domestic work. }\end{array}$ \\
\hline $\begin{array}{l}\text { Luiz Carlos Carvalho } \\
\text { de Castro (Masters - } \\
\text { 2015) }\end{array}$ & $\begin{array}{l}\text { The event of being: } \\
\text { a dialogical study of } \\
\text { philosophical thought } \\
\text { of Heidegger and } \\
\text { Bakhtin. }\end{array}$ & $\begin{array}{l}\text { The study aims to understand the constitution of from the } \\
\text { philosophical thought of M.Bakhtin and M. Heidegger. }\end{array}$ \\
\hline $\begin{array}{l}\text { Paulo Eduardo Aranha } \\
\text { de Sá Barreto Batista } \\
\text { (Doctoral candidate } \\
-2015 \text { ) }\end{array}$ & $\begin{array}{l}\text { The act of representing } \\
\text { the parliamentary } \\
\text { discourse. }\end{array}$ & $\begin{array}{l}\text { In reporting the speech of others the rapporteur of the } \\
\text { parliamentary discourse has two basic ways: maintain } \\
\text { the same words or paraphrasing them. In our doctoral } \\
\text { research project, we intend to observe the behavior of this } \\
\text { phenomenon in a specific situation:. The wording of the } \\
\text { minutes of the plenary sessions of João Pessoa Legislature } \\
\text { - Paraiba. In this case, the subject editor is simultaneously } \\
\text { free of transcription requirement, but attached to the fact that } \\
\text { the printed content will be appreciated by multiple subjects } \\
\text { speakers, parliamentarians, to be approved or not as a } \\
\text { historical record for camera proceedings. }\end{array}$ \\
\hline $\begin{array}{l}\text { Solange Carvalho } \\
\text { (Doctoral candidate } \\
\text { - 2015) }\end{array}$ & $\begin{array}{l}\text { The event of being } \\
\text { Xucuru. }\end{array}$ & $\begin{array}{l}\text { The purpose of this essay is to describe the event of being } \\
\text { Xucuru - indigenous group located in Pesqueira-PE, which } \\
\text { experiences one of his lost ancestral language redemption } \\
\text { process - the bias of the architectural Bakhtin's world. }\end{array}$ \\
\hline
\end{tabular}

\section{Final considerations}

The descriptions of the themes preferred, both in the course conclusion papers and in the studies carried out by the research initiation students, surrounding the philosophical ideas of Bakhtin, and in the research projects of the postgraduate students and in the empirical research carried out by us within the scope of the Postgraduate Arts Program of the UFPE, seem to indicate that Bakhtin's philosophical project in relation to experiments in language indicates a different path from the one proposed by science, especially linguistics, metaphysics and psychology which can only materialize for those who have lived the experience.

Returning to Bakhtin's claim for creating a philosophy firstly that this not conceive of being metaphysically as an object, as opposed to a subject, presupposes accepting that being is an event that can only happen in language. In that sense, thought will no longer be just a going to things themselves, using an instrument language, because if it is language 


\section{Conexão Letras}

that enables an opening up to the world and confers being on subjects, the path we have to take to reach the subject is the word.

Also, one must take into account the fact that understanding (meaning) the responsible act in the happening of being-in-the-world necessarily involves another type of understanding that is not reduced to or confused with a simple explanation that one can find in some universal founding system governed by reason, such as the rational methods (for founding and explaining) science. So in order to do a thought experiment using language, one cannot rest on a pre-understanding of a world already given, known and explained from a stabilized meaning. The intended understanding is that which can only be found in the duty-being of the act responsibly lived, that is, it involves that which life itself leads us to understand. This outlook opens a new path for thinking about the forms of knowledge of human life through language.

\section{References}

BAJTIN, Mijail M. Hacia una filosofia del acto ético. De los boradores y otros escritos. Trad.Tatiana Bubnova. Rubi (Barcelona): Anthropos, 1997.

BAKHTIN, M. Estética da Criação Verbal. Trad. Maria Ermantina G.G.Pereira. São Paulo: Martins Fontes, 1997b.

BERGSON, Henri. A evolução criadora. São Paulo: Martins Fontes, 2005.

SAMPAIO,M.C.H, ARAÚJO, K. D.de S., MACEDO, E.B.I. de. Bakhtin e Heidegger: caminhos para a compreensão e interpretação do acontecimento do ser, Bakhtiniana, vl. 10, n.3, 2015, pp. 186-204;225-242 http://revistas.pucsp.br/ .

SAMPAIO,M.C.H, Reflexões ético-filosóficas e bioéticas acerca do envelhecimento na perspectiva do desenvolvimento sustentável. Livro GED, Luciane de Paula (Org.), São Carlos: Pedro e João, 2014, pp.351-374.

SAMPAIO, M.C.H. Origens filosóficas da Ética em Bakhtin: re-leituras da Metafísica e da Fenomenologia ontológico-hermenêutica. Zandwais (Org.) História das Ideias. Diálogo entre linguagem, cultura e história. Porto Alegre: Editora UFRGS. Passo Fundo: Editora UPF, 2012, pp. 192-215.

SAMPAIO, M.Cristina Hennes. Ética e Ciências Humanas: diálogos filosóficos entre M.Bakhtin e E.Lévinas, Cadernos de Linguagem e Sociedade, vol.13(12), 2012, pp. 185-206.

VIEIRA, E.B. Manual de Gerontologia. Um Guia teórico-prático para profissionais, cuidadores e familiares. Rio de Janeiro: Revinter, 1996. 